\title{
Video-Assisted Thoracoscopic Surgery for Migration of a Kirschner Wire in the Spinal Canal: A Case Report and Literature Review
}

\author{
Spinal Kanal İcine Bir Kirschner Telinin Göçmesi Durumunda Video \\ Yardımlı Torakoskopik Cerrabi: Bir Olgu Sunumu ve Literatürün Gözden \\ Geçirilmesi
}

\author{
Yawei LI, Bing WANG, Guohua LV, Guangzhong XIONG, Weidong LIU \\ Second Xiangya Hospital of Central South University, Department of Spinal Surgery, Changsha, China
}

Corresponding Author: Bing WANG / E-mail: wangbingdr@yahoo.cn

\begin{abstract}
Orthopedic wires and pins are regularly used for the treatment of dislocations and bone fractures. Migration of these metallic fixation devices into the spinal canal is an uncommon complication. We present a 35-year-old man who underwent thoracic spinal canal migration of a Kirschner wire. The patient had undergone treatment of acromioclavicular joint dislocation with Kirschner wire fixation. Two months after the operation, a chest radiograph showed a Kirschner wire in the thoracic cavity. Chest computed tomography (CT) showed the object extended transversely across the spinal canal. Emergency video-assisted thoracoscopic surgery (VATS) was successfully performed to remove the Kirschner wire without any complication. The patient made an uneventful recovery and was discharged on the seventh day after surgery. In our opinion, it is important to pay attention to the migration of metallic fixation devices. Surgical removal of such migrated devices is necessary for preventing disastrous consequences. VATS is a safe and effective treatment in such cases.
\end{abstract}

KEYWORDS: Video-assisted thoracoscopic surgery, Kirschner wire, Migration, Thoracic spinal canal

öz

Ortopedik teller ve pinler, dislokasyon ve kemik kırıklarının tedavisi için sıklıkla kullanılır. Bu metalik fiksasyon cihazlarının spinal kanal içine göçmesi nadir bir komplikasyondur. Bir Kirschner telinin spinal kanala göçmesinin görüldüğü 35 yaşında bir erkek sunuyoruz. Hastada Kirschner teli fiksasyonuyla akromiyoklaviküler eklem dislokasyonu tedavisi yapılmıştı. Ameliyattan iki ay sonra bir akciğer filmi Kirschner telini torasik kavitede gösterdi. Göğüs bilgisayarlı tomografisi (BT) nesnenin spinal kanal içinden transvers olarak uzandığını gösterdi. Kirschner telini çıkarmak için acil video yardımlı torakoskopik cerrahi (VATS) herhangi bir komplikasyon olmadan başarıyla gerçekleştirildi. Hasta bir problem olmadan iyileşti ve cerrahiden sonra yedinci günde taburcu edildi. Bizce metalik fiksasyon cihazlarının göçmesine dikkat etmek önemlidir. Bu tür göçen cihazların cerrahi olarak çıkarılması çok ciddi sorunları önlemek açısından önemlidir. Bu tür vakalarda VATS güvenli ve etkin bir tedavidir.

ANAHTAR SÖZCÜKLER: Video yardımlı torakoskopik cerrahi, Kirschner teli, Torasik spinal kanal

\section{INTRODUCTION}

Acromioclavicular displacements and clavicular fractures frequently occur after traumatic lesions of the thorax. Orthopedic wires and pins are regularly used for the treatment of dislocations and bone fractures. Migration of these devices from the clavicle into the thoracic cavity is an uncommon but well-known complication of such procedures $(3,10,15)$. However, cases where such wires migrate transversally through the spinal cord at the T2/3 level and stop in the transverse foramen at the T2 level are extremely rare. We present an unusual case of such a migration of a Kirschner wire into the thoracic spinal canal. Emergency video-assisted thoracoscopic surgery (VATS) was successfully performed to remove the Kirschner wire that had migrated from the thoracic cavity to the spinal canal. The patient's recovery was uneventful, and he was discharged from the hospital on the seventh day after surgery.

\section{CASE REPORT}

A 35-year-old man was involved in a motorcycle accident and suffered dislocation of the left clavicle at the acromioclavicular joint. He underwent open reduction and internal fixation with 2 Kirschner wires at a local hospital. Two months later, when he was hospitalized for removal of the wires, a shoulder radiograph showed that one of the wires had migrated into the thoracic cavity. The patient was referred to our hospital for further treatment. A chest radiograph showed a Kirschner wire in the thoracic cavity (Figure 1). Subcutaneous 


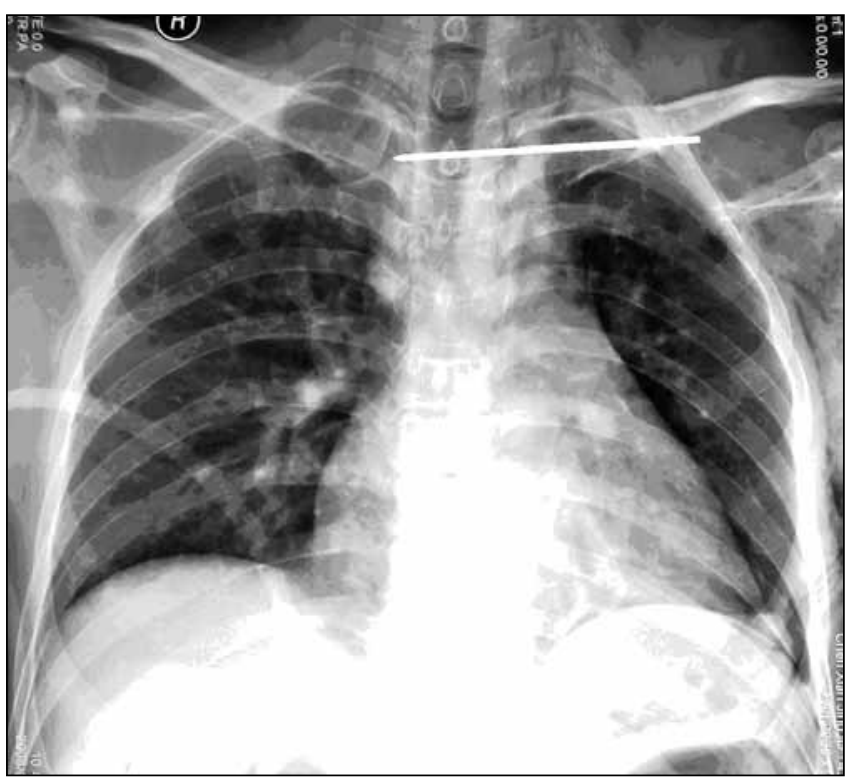

Figure 1: Chest X-ray showed intrathoracic location of the migrated wire. emphysema and hydropneumothorax were observed in the left thorax. Computed tomography (CT) of the chest showed that the object had extended transversely across the spinal canal (Figure 2).

Subsequently, left VATS was performed. The patient was placed in the right lateral decubitus position with a wide preparation and drape to allow conversion to an open procedure if necessary. The thoracoscopic portals were placed in the 4th intercostal space along the midaxillary line. Two $1.5-\mathrm{cm}$ skin incisions were made in the 3rd intercostal spaces along the axillary line and midaxillary line and used as operation channels. It was found that clear cerebrospinal fluid was overflowing at the crevasse, and we used surgical instruments to withdraw the object backwards and to the left. A 1-cm incision was made below the left acromion to aid in removing the Kirschner wire. The patient's recovery was uneventful, and he was discharged on the seventh day after surgery.

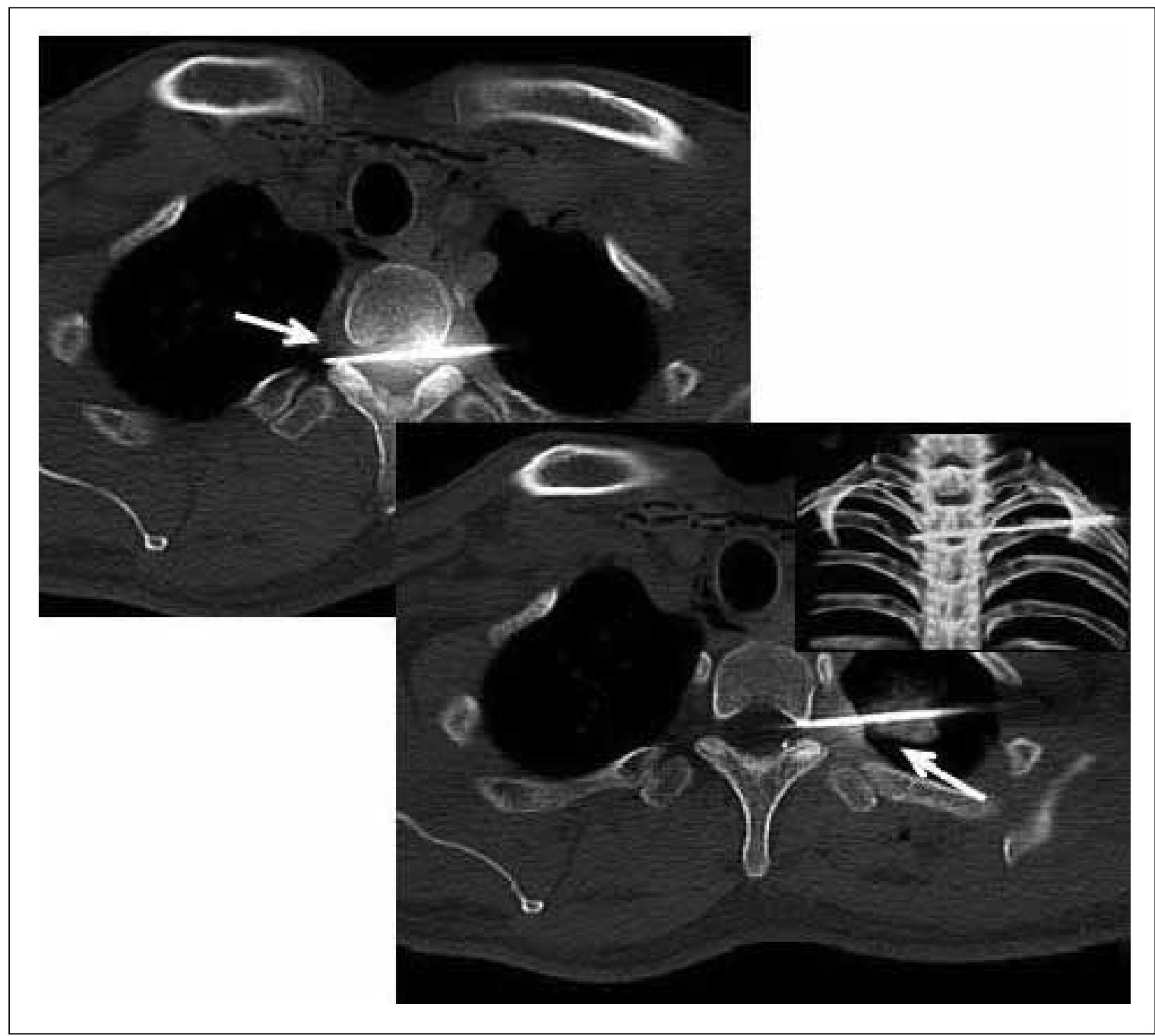

Figure 2:

Thoracic CT scan showed that the Kirschner wire had extended transversely across the spinal canal at the $T 2 / 3$ level. White arrow indicates the object. 


\section{DISCUSSION}

Intrathoracic migration of orthopedic wires and pins from the shoulder region is a rare but well-known complication. Metallic orthopedic-fixation devices have been used since the 1930s, but the incidence of intrathoracic migration of these devices is unknown (9). Cases of Kirschner wire migration inside the thorax have been reported since 1943 (11). Lyons FA reported 47 instances of wire migration; the device migrated after treatment of an acromioclavicular dislocation in 8 instances. The time gap between the introduction of the wire in the clavicular region and its migration to the thoracic cavity is reported to be highly variable (1 day to 21 years) (10). Injury to the arch vessels, pulmonary artery, heart, mediastinum, and esophagus has also been reported in such cases $(1,4,5,13,16,17)$. In the current case, the wire had been used for fixing the left acromioclavicular joint and it migrated transversally through the spinal region at the $T 2 / 3$ level and stopped in the transversal foramen at the T2 level. Interestingly, in our case, although the patient with thoracic dural puncture Kirschner who had leakage of cerebrospinal fluid, part from left shoulder pain, the patient did not have occipital headaches, neurological deficit, or any other discomfort. The nerve bundle within the dural sac had possibly been avoided the when Kirschner wire was slided into the spinal canal slowly. The mechanism underlying this migration into the thoracic spinal canal is not entirely clear. Various theories have been proposed to explain the reason behind the migration of Kirschner wires, including the great freedom of shoulder movements, breathing movements, negative intrathoracic pressure, gravitational force, and regional bony reabsorption $(9,10,13)$.

Surgical removal of migrated wires is considered mandatory in both symptomatic and asymptomatic cases $(7,10)$. Different authors have reported the use of sternotomy and thoracotomy for this purpose $(12,14)$. VATS has also been reported to be a useful modality in such cases $(2,6,8)$. In our experience, CT scan has proven to be useful in preoperative evaluation, especially in deciding on the operative approach. In this case, VATS was the surgical approach of choice for removing the wire that migrated transversally through the spinal cord. To our knowledge, such a case has not been previously described. We think that VATS has the following advantages: (1) patients suffer less injury because of small incisions (approximately $1.5 \mathrm{~cm}$ ) and thoracotomy can be avoided; (2) recovery is also quicker, which leads to decreased hospital stay and expenses incurred by the patient at the hospital; (3) VATS causes less injury to the patients' organs. Thus, complications pertaining to respiratory and cardiovascular function are greatly reduced. However, surgeons should check for surgical indications of VATS to ensure that patients benefit from the procedure. This approach is safe and useful in hemodynamically stable patients who can tolerate the lateral decubitus position and single-lung ventilation. VATS should be performed only by an experienced surgeon who has sufficient expertise for converting this technique into an open procedure if required.
VATS is not recommended if injuries to vital structures are suspected and median sternotomy or thoracotomy must be immediately performed in such cases (1).

Our report confirms that fixation of sternoclavicular joint dislocation by using metallic devices should be considered a very hazardous procedure. Alltypes of wires (smooth, threaded, or bent) have been reported to migrate (10). Surgeons should be aware of this potentially lethal complication. Several points should be noted: (1) the patients should be regularly followed-up both clinically and radiographically until removal of the Kirschner wires; (2) fixation should be removed on time; and (3) surgical removal should be performed immediately after wire migration is recognized. Previous studies have reported considerable displacement of Kirschner wires within only a few hours after diagnosis (13). In addition, surgeons should try to use a clavicular hook plate instead of simple Kirschner wire to avoid similar incidents. With the development of endoscopic techniques, VATS has become an effective and more widely used technique, with advantages such as decreased invasiveness and faster recovery. However, surgeons should always strictly follow surgical indications of VATS; thoracotomy is preferable when the safety of the procedure is not assured.

\section{REFERENCES}

1. Antoine S, Matthieu T, Fre'de'ric D, Jacques J: Transaortic migration of a Steinman wire from the shoulder. Eur J Cardiothoracic Surg 40:517-519, 2011

2. Calkins CM, Moore EE, Johson JL, Smith WR: Removal of an intrathoracic migrated fixation pin by thoracoscopy. Ann Thorac Surg 71:368-370, 2001

3. De Jong KP, Sukul DM: Anterior sternoclavicular dislocation: A long-term follow-up study. J Orthop Trauma 4:420-423, 1990

4. Evaldo M, Marcio PR, Marcus VC: Transmediastinal migration of Kirschner wire. Interact CardioVasc Thorac Surg 7:869-870, 2008.

5. Gerlach D, Wemhoner SR, Ogbuihi S: 2 cases of pericardial tamponade caused by migration of fracture wires from the sternoclavicular joint. J Z Rechtsmed 93:53-60, 1984

6. Grand JG, Bureau SC: Video-assisted thoracoscopic surgery for pneumothorax induced by migration of a K-Wire to the chest. J Am Anim Hosp Assoc 47(4):268-275, 2011

7. Janssens de Varebeke B, Van Osselaer G: Migration of Kirschner's pin from the right sternoclavicular joint resulting in perforation of the pulmonary artery main trunk. Acta Chir Belg 93:287-291, 1993

8. Kamiyoshihara M, Kakegawa S, Otani Y, Morishita Y: Videoassisted thoracoscopic surgery for migration of an orthopedic fixation wire in the mediastinum: Report of a case. Kyobu Geka 58(5):403-405, 2005

9. Kumar P, Godbole R, Rees M, Sarkar P: Intrathoracic migration of a Kirschner wire. J R Soc Med 95(4):198-199, 2002

10. Lyons FA, Rockwood CA: Migration of pins used in operations on the shoulder. J Bone Joint Surg 72A: 1262-1267, 1990 
11. Mazet R: Migration of a Kirschner wire from the shoulder region into the lung: Report of two cases. J Bone Joint Surg Am 25:477-483, 1943

12. Nordback I, Markkula H: Migration of Kirschner pin from clavicle into ascending aorta. J Acta Chir Scand 151:177-179, 1985

13. Rajesh PB, Nair KK: Unusual migration of a Kirschner wire. Eur J Cardiothorac Surg 5:164, 1991

14. Tubbax $H$, Hendzel P, Sergeant P: Cardiac perforation after Kirschner wire migration. Acta Chir Belg 89:309-311, 1989
15. Veres L, Kiss $R$, Boros $M$, Enyedi A, Takács I, Kollár S, Damjanovich L, Sz Kiss S: Intrathoracic migration of Kirschner wires. Magy Seb 62(6):353-356, 2009

16. Wada S, Noguchi T, Hashimoto T, Uchida Y, Kawahara K: Successful treatment of a patient with penetrating injury of the esophagus and brachiocephalic artery due to migration of Kirschner wires. J Ann Thorac Cardiovasc Surg 11:313-315, 2005

17. Wu YH, Lai $\mathrm{CH}$, Luo $\mathrm{CY}$, Tseng YL: Tracheoinnominate artery fistula caused by migration of a Kirschner wire. Eur J Cardiothorac Surg 36:214-216, 2009 